\title{
Metal Transporter Zip14 (Slc39a14) Deletion in Mice Increases Manganese Deposition and Produces Neurotoxic Signatures and Diminished Motor Activity
}

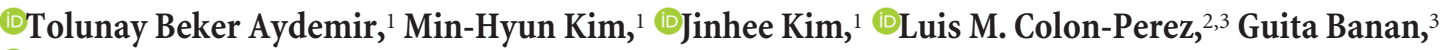 \\ (T)Thomas H. Mareci, ${ }^{3,4}$ Marcelo Febo, ${ }^{2,3}$ and Robert J. Cousins ${ }^{1,4}$ \\ ${ }^{1}$ Food Science and Human Nutrition Department, Center for Nutritional Sciences, College of Agricultural and Life Sciences, ${ }^{2}$ Department of Psychiatry, \\ ${ }^{3} \mathrm{McKnight}$ Brain Institute, and ${ }^{4}$ Department of Biochemistry and Molecular Biology, College of Medicine, University of Florida, Gainesville, Florida 32611
}

\begin{abstract}
Mutations in human ZIP14 have been linked to symptoms of the early onset of Parkinsonism and Dystonia. This phenotype is likely related to excess manganese accumulation in the CNS. The metal transporter ZIP14 (SLC39A14) is viewed primarily as a zinc transporter that is inducible via proinflammatory stimuli. In vitro evidence shows that ZIP14 can also transport manganese. To examine a role for ZIP14 in manganese homeostasis, we used Zip14 knock-out (KO) male and female mice to conduct comparative metabolic, imaging, and functional studies. Manganese accumulation was fourfold to fivefold higher in brains of Zip14 KO mice compared with young adult wild-type mice. There was less accumulation of subcutaneously administered ${ }^{54} \mathrm{Mn}$ in the liver, gallbladder, and gastrointestinal tract of the KO mice, suggesting that manganese elimination is impaired with Zip14 ablation. Impaired elimination creates the opportunity for atypical manganese accumulation in tissues, including the brain. The intensity of MR images from brains of the Zip14 KO mice is indicative of major manganese accumulation. In agreement with excessive manganese accumulation was the impaired motor function observed in the Zip14 KO mice. These results also demonstrate that ZIP14 is not essential for manganese uptake by the brain. Nevertheless, the upregulation of signatures of brain injury observed in the Zip $14 \mathrm{KO}$ mice demonstrates that normal ZIP14 function is an essential factor required to prevent manganese-linked neurodegeneration.
\end{abstract}

Key words: dystonia; neurodegeneration; neuroinflammation; Parkinson's; transport; zinc

Significance Statement

Manganese is an essential micronutrient. When acquired in excess, manganese accumulates in tissues of the CNS and is associated with neurodegenerative disease, particularly Parkinson-like syndrome and dystonia. Some members of the ZIP metal transporter family transport manganese. Using mutant mice deficient in the ZIP14 metal transporter, we have discovered that ZIP14 is essential for manganese elimination via the gastrointestinal tract, and a lack of ZIP14 results in manganese accumulation in critical tissues such as the brain, as measured by MRI, and produces signatures of brain injury and impaired motor function. Humans with altered ZIP14 function would lack this gatekeeper function of ZIP14 and therefore would be prone to manganeserelated neurological diseases.

\section{Introduction}

Manganese is a nutritionally essential micronutrient that can influence health. Considerable attention has been given to manga-

Received Jan. 30, 2017; revised May 5, 2017; accepted May 8, 2017.

Author contributions: T.B.A., M.F., and R.J.C. designed research; T.B.A., M.-H.K., J.K., L.M.C.-P., and G.B. performed research; T.B.A., T.H.M., M.F., and R.J.C. analyzed data; T.B.A. and R.J.C. wrote the paper.

This project was supported in part by National Institute of Diabetes and Digestive and Kidney Diseases Grant 5R01-DK-094244 and the Boston Family Endowment Funds of the University of Florida to R.J.C. M.-H.K. is an Alumni Graduate Fellow of the College of Agricultural and Life Sciences. Support was also provided by the National High Magnetic Field Laboratory Advanced Magnetic Resonance Imaging and Spectroscopy Facility (under National Science Foundation Cooperative Agreement No. DMR-1157490 and the State of Florida).

The authors declare no competing financial interests. nese toxicity in humans due to environmental contamination, occupational activities, and overconsumption of manganese-rich dietary supplements (Buchman, 2014; O'Neal and Zheng, 2015; Freeland-Graves et al., 2016). Manganese accumulation has been carefully documented as contributing to neurotoxicity in rodent and nonhuman primate models (Guilarte, 2013). In human subjects, the spectrum of manganese-related neurological disease in-

Correspondence should be addressed to Dr. Robert J. Cousins, Food Science and Human Nutrition Department, College of Agricultural and Life Sciences, 572 Newell Drive, P.O. Box 110370, Gainesville, FL 32611. E-mail: cousins@ufl.edu.

DOI:10.1523/JNEUROSCI.0285-17.2017

Copyright $\odot 2017$ the authors $\quad 0270-6474 / 17 / 375996-11 \$ 15.00 / 0$ 
cludes Parkinson's disease and dystonia (Horning et al., 2015). Many conditions contribute to these disorders, including chronic liver disease (Quadri et al., 2012; Tuschl et al., 2012), drug addiction (Stepens et al., 2008), and immune responses, leading to neuroinflammation (Burton and Guilarte, 2009; Horning et al., 2015).

Numerous metal transporters have been implicated as contributing factors for excess manganese accumulation and neurological disorders (Horning et al., 2015). Components of iron metabolic pathways including divalent metal transporter-1 (DMT-1), transferrin receptor (TFR), and the iron efflux transporter ferroportin-1 (FPN1) have been implicated in manganese metabolism (Buchman, 2014). Animal models of genetic disorders of iron metabolism support this involvement (Chua and Morgan, 1997; Kim et al., 2013; Seo and WesslingResnick, 2015).

Recently, transporters most frequently identified with roles in zinc metabolism have also been implicated in manganese metabolism (Horning et al., 2015). These transporters are found in two families. The ZnT (SLC30A1-10) family functions to lower intracellular metal concentrations through efflux at the plasma membrane or through a secretory route (Huang and Tepaamorndech, 2013; Kambe et al., 2015) The ZIP (SLC39A 1-14) family functions to increase intracellular metal concentrations through influx at the plasma membrane or from endosomes, mitochondria, or lysosomes (Lichten and Cousins, 2009; Jeong and Eide, 2013). Mutations that alter function/localization of ZnT10 (SLC30A10) result in hypermanganesmia as found in Parkinson's disease and dystonia (Quadri et al., 2012; Tuschl et al., 2012; Leyva-Illades et al., 2014). In addition, ZIP8 (SLC39A8) has been linked to disorders of manganese transport (Boycott et al., 2015; Park et al., 2015).

Zip14 is induced by proinflammatory cytokines, including IL-6, TNF- $\alpha$, and IL-1B, and by nitric oxide and that ZIP14 (SLC39A14) and drastically influences zinc homeostasis in vivo (Liuzzi et al., 2005; Lichten et al., 2009). Mice with a Zip14 deletion exhibit major specific phenotypic changes including metabolic endotoxemia, reduced hepatocyte regenerative capacity, adipocyte hypertrophy, and zinc dyshomeostasis during sepsis (Aydemir et al., 2012a,b, 2016; Guthrie et al., 2015; Wessels and Cousins, 2015; Troche et al., 2016). Despite the considerable attention given to ZIP14 in mice in terms of zinc transport and related physiology, in vitro evidence suggests that ZIP14 can transport manganese (Girijashanker et al., 2008; Pinilla-Tenas et al., 2011; Fujishiro et al., 2014).

Recently, mutations in Zip14 have been identified in a group of young patients who presented clinically with greatly elevated whole-blood manganese concentrations, abnormal MR images of brain characteristic of manganese accumulation, and a diagnosis of childhood-onset parkinsonism-dystonia (Tuschl et al., 2016). They also showed altered locomotor activity and manganese accumulation in zebrafish with a Zip14 mutation. These significant findings led us to use a systems metabolic approach to understand how manganese homeostasis can be controlled by ZIP14 in a mammalian model. Accordingly, we found that Zip14 knock-out (KO) mice lacking ZIP14 have a spontaneous manganism syndrome with profound accumulation of manganese in brain accompanied by decreased motor activity. The results demonstrate that ZIP14 is important in manganese homeostasis to limit manganese in the CNS and is associated with physiologic complications.

\section{Materials and Methods}

\section{Animals}

The design and validation of the conventional Zip14 KO (Zip14 $\left.{ }^{-/-}\right)$ murine strain has been described previously (Aydemir et al., 2012b). The breeding colony uses backcrosses with other mice of the C57BL/6 and $129 S 5$ background. The mice used in these experiments were of the F12 generation or later. After weaning, the mice were fed ad libitum a commercial chow diet that contained $93 \mathrm{mg} \mathrm{Mn} / \mathrm{kg}$ (catalog \#7012, Harlan) and tap water and were maintained on a $12 \mathrm{~h}$ light/dark cycle. Both female and male mice were used as young adults ( $8-16$ weeks of age). Gender differences were evaluated in most experiments. Mice were killed by exsanguination using cardiac puncture under isoflurane anesthesia. Protocols were approved by the University of Florida Institutional Animal Care and Use Committee.

\section{Manganese and zinc metabolism}

In experiments to evaluate manganese metabolism using ${ }^{54} \mathrm{Mn}$, the mice were fasted for $4 \mathrm{~h}$ before being used for experiments. Each mouse received $5 \mu \mathrm{Ci}$ of the radioisotope in $250 \mu \mathrm{l}$ by gavage, under anesthesia, $4 \mathrm{~h}$ before they were killed. In companion experiments, each mouse received $3 \mu \mathrm{Ci}$, s.c., of ${ }^{54} \mathrm{Mn}$, and they were killed $4 \mathrm{~h}$ later. The entire excised small intestine was perfused with a metal chelating buffer (10 mM EDTA, $10 \mathrm{~mm}$ HEPES, and $0.9 \% \mathrm{NaCl}$ ) to collect the luminal contents containing unabsorbed and excreted ${ }^{54} \mathrm{Mn}$. To compare ${ }^{54} \mathrm{Mn}$ metabolism to that of zinc, the identical protocol was followed using ${ }^{65} \mathrm{Zn}(2 \mu \mathrm{Ci} /$ mouse). Specific activities of the ${ }^{54} \mathrm{Mn}$ and ${ }^{65} \mathrm{Zn}$ (PerkinElmer) were 104 and $2 \mathrm{mCi} / \mathrm{mg}$, respectively, at the time of administration. Radioactivity in weighed aliquots of tissue and luminal contents was measured by gamma ray solid scintillation spectrometry.

\section{Metal assays}

To measure manganese and zinc concentrations by flame atomic absorption spectrophotometry (AAS), weighed aliquots of tissue were digested at $95^{\circ} \mathrm{C}$ for at least $3 \mathrm{~h}$ in $\mathrm{HNO}_{3}$. Samples were diluted in Milli-Q water before AAS analysis Aydemir et al., 2012b). Whole blood (500 $\mu$ l) was assayed for the measurement of Mn concentration after acid digestion. Serum (diluted in water) was used to measure the $\mathrm{Zn}$ concentration.

\section{Quantitative PCR analyses}

Tissue samples were flash frozen in liquid nitrogen and stored at $-80^{\circ} \mathrm{C}$. RNA was isolated following homogenization in TRIzol reagent using a Bullet Blender homogenizer. Total RNA was used to measure relative mRNA abundance by quantitative PCR (qPCR). Primer/probe sequences were published previously (Wessels and Cousins, 2015; Aydemir et al., 2016; Troche et al., 2016). TBP mRNA was the normalizer for relative expression comparisons.

\section{Western analysis}

Tissue aliquots stored at $-80^{\circ} \mathrm{C}$, as above, were homogenized in RIPA lysis buffer with protease and phosphatase inhibitors (Thermo Scientific and AG Scientific) added along with the PMSF (Sigma-Aldrich) using the Bullet Blender. Solubilized proteins were separated by 10\% SDS-PAGE and transferred to nitrocellulose membranes using Ponceau Red to confirm transfer. Visualization was by chemiluminesence (SuperSignal, Thermo Fisher) and digital imaging (Protein Simple). Details are described previously (Troche et al., 2016). In one series of experiments, proximal sections of small intestine were removed from wild-type (WT) and Zip14 KO mice for isolation of biotinylated proteins from separated apical and basolateral membranes. These procedures were described in detail previously (Guthrie et al., 2015). Rabbit anti-mouse ZIP14 and ZIP8 antibodies were produced in-house and were affinity purified and characterized as described previously (Liuzzi et al., 2005; Aydemir et al., 2009). Antibodies for $\mathrm{Na}^{+} / \mathrm{K}^{+}$-ATPase (Santa Cruz Biotechnology) and sodium-glucose cotransporter 1 (SGLT1), translocator protein (TSPO), and tubulin (Abcam) were obtained from the indicated suppliers.

\section{Magnetic resonance imaging}

Mice of both genotypes were anesthetized and killed by exsanguination via cardiac puncture. The brains were immediately placed in $4 \%$ formalin for fixation. Within $24 \mathrm{~h}$, the brains were rinsed in PBS and then placed in 
pairs in Fluorinert oil (FC-43, 3M/Sigma-Aldrich) and finally in fresh Fluorinert for imaging. The excised brains were imaged using a 17.6 tesla magnetic resonance spectrometer interfaced with a Paravision 6.0 console (Bruker) and a 20-mm-inner diameter birdcage coil (In Vivo). Simultaneous imaging of two brains from each condition (one WT brain and one Zip14 KO brain) was used to allow for unbiased by size and intensity comparisons. The MRI protocol consisted of a T1-weighted 3D FLASH sequence with a $30^{\circ}$ flip angle, a repetition time of $80 \mathrm{~ms}$, and an echo time of $4 \mathrm{~ms}$. An average of six replications allowed a spatial resolution of $75 \mu \mathrm{m}^{3}$. The total scan time was $4 \mathrm{~h}$ and $38 \mathrm{~min}$.

\section{Open field spontaneous activity}

To monitor spontaneous activity, individual mice were placed in a VersaMax Animal Activity Monitoring System (AccuScan Instruments) for a $30 \mathrm{~min}$ test session. The system consisted of four animal activity cages made of clear acrylic $40 \mathrm{~cm}^{3}$ square chambers equipped with infrared photocell beams. Horizontal activity, total distance, moving time, clockwise revolution, counterclockwise revolution, margin distance, and resting time data were automatically collected in the dark using the Versamax activity monitor and analyzer software system.

\section{Motor function and gastrointestinal motility tests}

Motor function for all mice was tested in the light phase. All tests were performed as described previously (Sampson et al., 2016).

Balance beam traversal. The beam was constructed of four segments of $0.25 \mathrm{~m}$ in length with progressively narrower widths $(3.5,2.5,1.5$, and 0.5 $\mathrm{cm})$. The widest segment acted as a loading platform, and the narrowest ended at the home cage. After $2 \mathrm{~d}$ of training, the mice were timed over three trials to traverse the beam.

Hindlimb clasping reflex scoring. Mice were gently lifted upward by the tail and observed over $\sim 5-10 \mathrm{~s}$. A score of 0 was assigned if they were freely moving their limbs and extending them outward. Scores of 1,2 , and 3 were assigned if they were displaying an inward clasp of one hindlimb, two hindlimbs, or total paralysis of both hindlimbs, respectively.

Cylinder test. Mice were placed in a translucent container $(12 \mathrm{~cm}$ width, $20 \mathrm{~cm}$ height), and forelimb steps were counted when the mice moved both forelimbs together from the floor to the wall of the cylinder in one movement.

Inverted grid. The mice were placed in the center of a 26 by $38 \mathrm{~cm}$ screen with $1-\mathrm{cm}^{2}$-wide mesh. The screen was inverted, and the mice were timed for $60 \mathrm{~s}$ until they released their grip or held on.

Pole descent. A pole $(0.5 \mathrm{~m}$ long, $1 \mathrm{~cm}$ in diameter $)$ was placed into the home cage. After $2 \mathrm{~d}$ of training, the time required to descend from top of the pole to the bottom was measured.

Gastrointestinal motility test and fecal output. Following an overnight fast, the mice were given TRITC-dextran $(40,000 \mathrm{Da})$ via gavage. After $2 \mathrm{~h}$, the mice were killed and the amount of TRITC-dextran remaining in the luminal contents of the gastrointestinal (GI) tract was measured by spectrofluorometry at Excitation/Emission 550/577 nm. The TRITCdextran concentration was calculated from a standard curve, and values were divided by tissue weight (stomach) or length (intestine and colon). To measure fecal output, mice were transferred from their home cage to a $12 \times 20 \mathrm{~cm}$ translucent cylinder, and fecal pellets produced over $5 \mathrm{~min}$ were counted.

\section{Statistics}

Data are presented as the mean \pm SEM. Significance was assessed by Student's $t$ test for single comparisons and by ANOVA/Tukey's test for multiple comparisons. Statistical significance was set at $p<0.05$.

\section{Results}

Excess brain manganese accumulation in Zip14 KO mice Using a conventional Zip14 KO mouse model, we measured manganese, zinc, and iron concentrations in whole blood/serum, liver, and brain at steady state. Our results revealed that manganese concentrations were greater in the whole blood and brain (Fig. 1A,B), and lower in the liver (Fig. 1C) of Zip14 KO mice when compared with WT controls. A compelling feature of these data is that these mice were young adults and were fed a standard
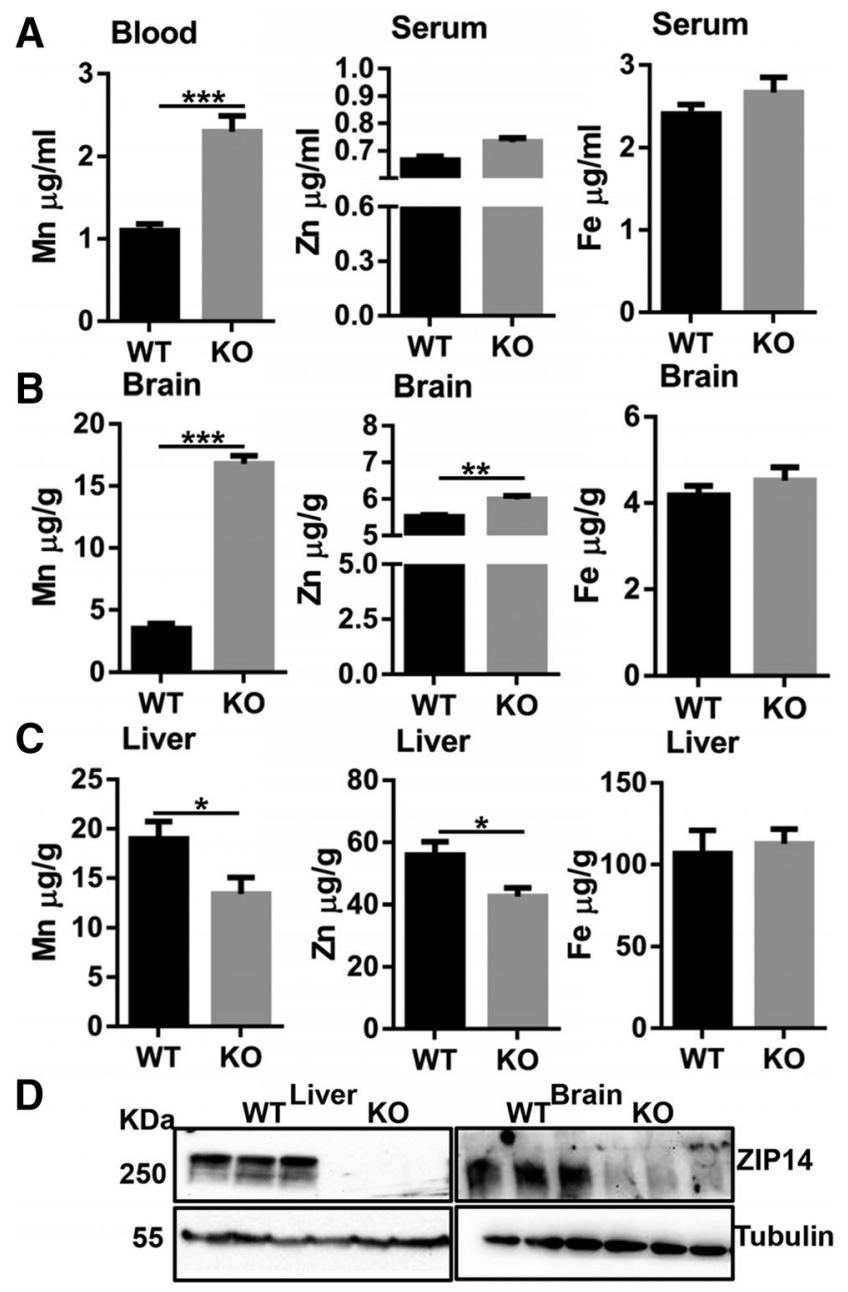

Figure 1. Deletion of Zip 14 leads to manganism in mice. $\mathrm{Mn}, \mathrm{Zn}$, and Fe concentrations were measured by Atomic Absorption Spectroscopy (AAS). A, Whole-blood Mn and serum Zn and Fe concentrations. $\boldsymbol{B}, \mathrm{Mn}, \mathrm{Zn}$, and Fe concentrations in brain. $\boldsymbol{C}, \mathrm{Mn}, \mathrm{Zn}$, and Fe concentrations in liver. $\boldsymbol{D}, \mathrm{ZIP} 14$ abundance in liver and brain. Values are reported as the mean \pm SEM. $N=6-7$ (equal number of female and male mice of each genotype were included). ${ }^{*} p<0.05,{ }^{* *} p<$ $0.01,{ }^{* * *} p<0.001$. Student's $t$ test for WT and Zip 14 KO comparison.

chow diet with no supplemental manganese where the Zip14 ablation was the variable. Differences in brain and liver zinc concentrations between WT and KO mice mirrored those of manganese but were of lesser magnitude. In contrast, iron concentrations in serum, brain, and liver were not different between WT and KO mice. Deletion of ZIP14 in the KO mice is demonstrated in Figure $1 D$.

\section{Ablation of Zip14 results in less effective blood manganese elimination}

The greater blood manganese concentrations (Fig. 1A) in Zip14 $\mathrm{KO}$ mice led to the hypothesis that ZIP14 might have a role in the elimination of absorbed manganese. Therefore, we measured radioactivity in whole blood, intestinal tissue, and the intestinal contents of WT and KO mice after administration of ${ }^{54} \mathrm{Mn}$ by intragastric gavage and separately by subcutaneous injection. Following both routes of administration, the amount of ${ }^{54} \mathrm{Mn}$ in whole blood was substantially greater in Zip14 KO mice when compared with WT mice (Fig. 2A). Following gavage, the amount of ${ }^{54} \mathrm{Mn}$ in intestinal tissue was not different between WT and Zip14 KO female mice. The amount of intestinal ${ }^{54} \mathrm{Mn}$ was far 
A Gavage

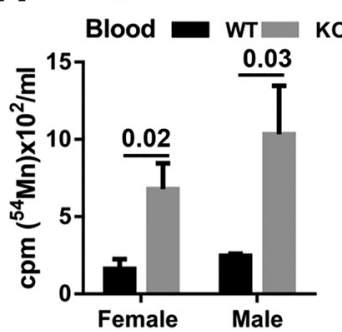

C Subcutaneous Injection

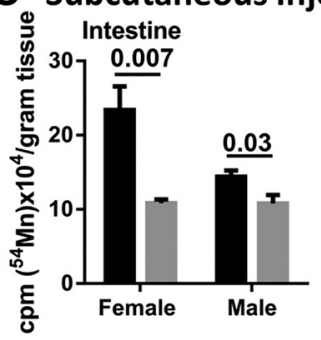

Subcutaneous Injection B Gavage
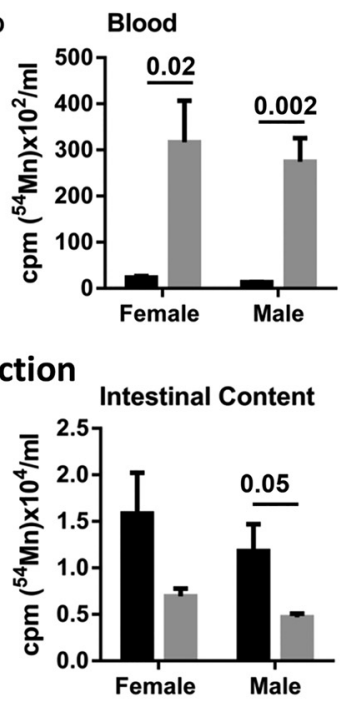

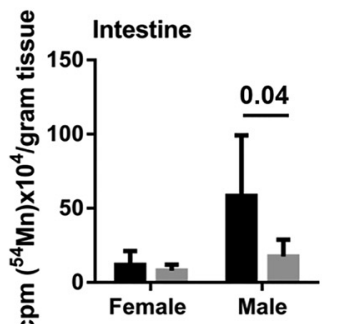

D Apical

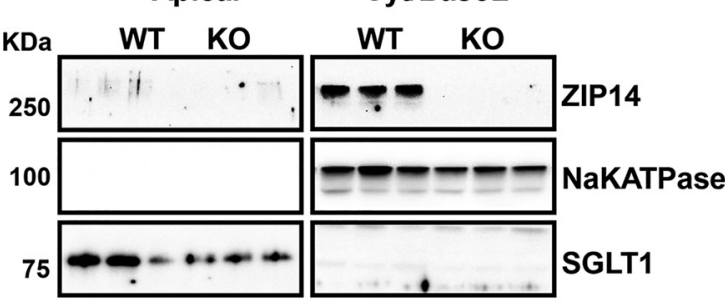

Figure 2. Reduction of endogenous manganese loss in Zip $14 \mathrm{KO}$ mice. Mice were administered ${ }^{54} \mathrm{Mn}$ via either gavage or subcutenous injection, and $4 \mathrm{~h}$ later radioactivity was measured. $\mathrm{A}$, Amount of ${ }^{54} \mathrm{Mn}$ in total blood. $\boldsymbol{B}$, Amount of ${ }^{54} \mathrm{Mn}$ in intestinal tissue and intestinal luminal contents of WT and Zip $14 \mathrm{KO}$ mice when administered by oral gavage. $\boldsymbol{C}$, Amount of ${ }^{54} \mathrm{Mn}$ in intestine tissue and intestinal luminal contents of WT and Zip14 K0 mice when administered by subcutaneous injection. $\boldsymbol{D}$, Location of ZIP14 at the basolateral membrane of enterocytes from WT mice as measured by biotinylation and Western analysis. Values are reported as the mean \pm SEM. $N=6-7$. Student's $t$ test for WT and Zip 14 KO comparison for each gender.

\section{A Gavage}
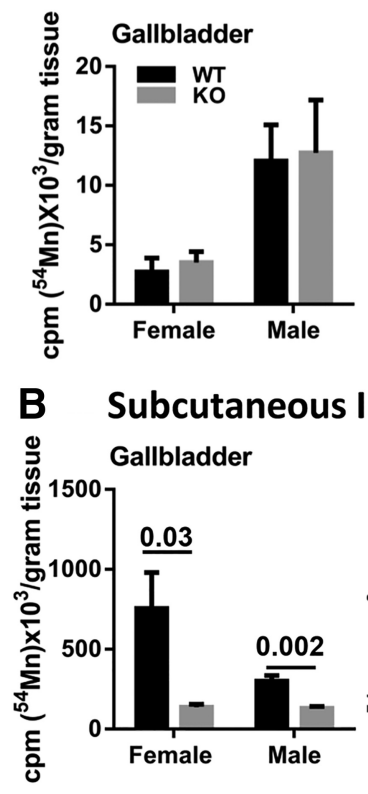

C
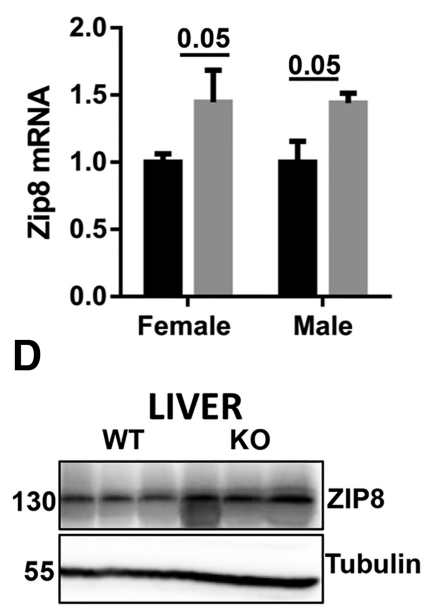

Figure 3. Comparison of ${ }^{54} \mathrm{Mn}$ metabolism and expression of Zip8 in livers of WT and Zip 14 KO mice. A, Amount of ${ }^{54} \mathrm{Mn}$ in gallbladder and liver tissue of WT and Zip $14 \mathrm{KO}$ mice following oral gavage. $\boldsymbol{B}$, Amount of ${ }^{54} \mathrm{Mn}$ in gallbladder and liver tissue of WT and Zip 14 KO mice following subcutaneous injection. C, Transcript of Zip8 was measured by qPCR. D. Hepatic ZIP8 protein abundance was measured by Western blot. Values are reported as the mean \pm SEM. $N=6-7$. Student's $t$ test for WT and Zip14 KO comparison for each gender.

greater in the WT male mice, but was significantly less in Zip14 $\mathrm{KO}$ male mice (Fig. $2 B$ ). Interestingly, the amount of ${ }^{54} \mathrm{Mn}$ from the oral dose found in the intestinal contents was lower in the female mice. Male Zip14 KO mice had more ${ }^{54} \mathrm{Mn}$ in the intestinal contents than male WT mice, but the difference was not statistically significant. These data suggest that intestinal manganese absorption was lower in male mice. When administered subcutaneously, the amount of ${ }^{54} \mathrm{Mn}$ was lower in the intestinal tissue and the intestinal contents of $\mathrm{Zip} 14$ $\mathrm{KO}$ mice of both genders (Fig. $2 C$ ), suggesting that systemic manganese elimination was much less effective when Zip14 was deleted. A likely explanation for the lower ${ }^{54} \mathrm{Mn}$ content in the intestine via subcutaneous administration is that ZIP14 is localized to the basolateral membrane of enterocytes. We evaluated the localization of ZIP14 in the small intestine (Fig. 2D). Proteins on the apical site of the intestine were separated from basolateral membrane localized proteins via biotinylation and immunoprecipitation with Sepharose beads. The basolateral membrane protein marker $\mathrm{Na}^{+} / \mathrm{K}^{+}$ATPase and apical membrane protein marker SGLT1, as controls, confirmed that ZIP14 was localized to the basolateral membrane of WT mice and was absent in the Zip14 KO mice.

Hepatic manganese uptake is reduced with Zip14 ablation

Manganese homeostasis is regulated primarily through the hepatobiliary excretion (Buchman, 2014; Horning et al., 2015; O'Neal and Zheng, 2015). Thus, we evaluated the influence of ZIP14 on manganese uptake into the hepatobiliary pathway. No difference was found between WT and Zip14 KO mice in the amount of ${ }^{54} \mathrm{Mn}$ in the gallbladder and the liver when ${ }^{54} \mathrm{Mn}$ was administered via gavage (Fig. $3 A$ ). In contrast, the amount of ${ }^{54} \mathrm{Mn}$ was significantly lower in the gallbladder and the liver of Zip14 $\mathrm{KO}$ mice when ${ }^{54} \mathrm{Mn}$ was injected subcutaneously (Fig. 3B). This finding is in congruence with the discovery that the amount of ${ }^{54} \mathrm{Mn}$ was much higher (14-fold to 20-fold) in the whole blood of the Zip14 KO mice 
when ${ }^{54} \mathrm{Mn}$ was administered via subcutaneous injection (Fig. 2A). We interpret this differential as indicating that, in the absence of ZIP14, hepatic manganese uptake was maintained by a less efficient manganese transport system. Metal transporters that potentially could function in that role in liver were measured at the transcript level. Those for ZnT10 and DMT1 as well as transferrin receptor were not different between WT and KO mice (data not shown). In contrast, hepatic Zip8 transcript levels were significantly higher in the Zip14 KO mice compared with WT controls (Fig. 3C). Furthermore, the abundance of hepatic ZIP8 protein was found to be greater in Zip14 KO male mice (Fig. 3D). These results suggest a possible role for ZIP8 in hepatic manganese metabolism, particularly when ZIP14 is dysfunctional, as in the $\mathrm{KO}$ mice.

\section{${ }^{54} \mathrm{Mn}$ uptake and magnetic resonance imaging reveal that deletion of $Z i p 14$ drastically influences manganese accumulation in brain}

To test the influence of ZIP14 on manganese brain accumulation, we have conducted comparative ${ }^{54} \mathrm{Mn}$ and ${ }^{65} \mathrm{Zn}$ uptake studies. When ${ }^{54} \mathrm{Mn}$ was administered either via gavage or subcutaneous injection, Zip14 KO mice accumulated much greater amounts of ${ }^{54} \mathrm{Mn}$ in brain when compared with WT control mice (Fig. 4A,B). By comparison, the differential in ${ }^{65} \mathrm{Zn}$ uptake by the brain between the Zip14 KO and WT mice was lower (Fig. $4 C, D$ ). Of note, we did not find any difference in the amount of ${ }^{59} \mathrm{Fe}$ between WT and Zip14 KO mice (data not shown). In an effort to identify factors that might contribute to the excess manganese in the brain of Zip14 KO mice, we have measured Zip8, Znt10, Dmt1, Fpn, and Tfr transcripts. Among them, only Dmt1 transcripts exhibited a significantly greater abundance $(p<0.05)$ in Zip14 KO compared with WT mice (Fig. 4E).

To more closely evaluate the pattern of manganese accumulation, we excised brains from WT and Zip14 KO mice for subsequent MRI analysis. As shown in Figure 5, images of signal intensity from the brains of the Zip14 KO mice is far greater than that of the WT mice. The images received no enhancement and represent only the signal produced by endogenous manganese in brains of the two genotypes. Of major interest is the marked signal intensity of the hippocampus, striatum, and cerebellum of the Zip14 KO brains.

Zip14 KO mice display impaired locomotor and gastrointestinal function

Manganism is known to cause motor impairment that resembles Parkinson's disease (Peres et al., 2016). To test for an abnormal motor phenotype in the Zip14 KO mouse model, we used loco-

\section{B Subcutaneous Injection}

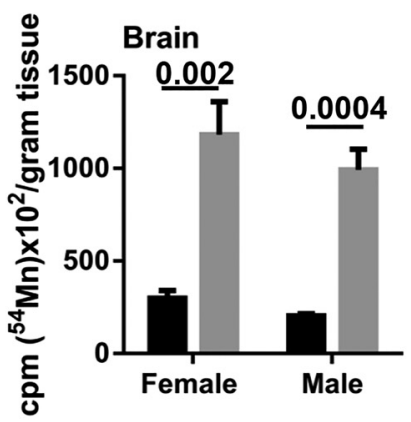

D Subcutaneous Injection

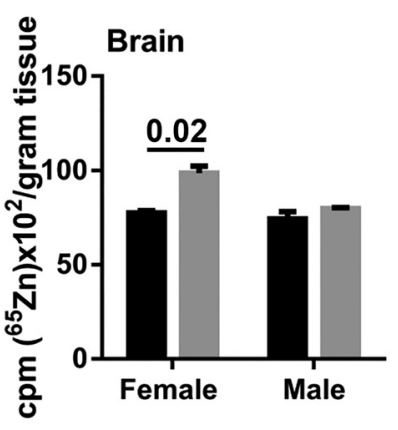

Figure 4. Comparison of ${ }^{54} \mathrm{Mn}$ and ${ }^{65} \mathrm{Zn}$ metabolism and DMT1 expression in brains of WT and Zip14 KO mice. A, Amount of ${ }^{54} \mathrm{Mn}$ in brain tissue of WT and Zip $14 \mathrm{KO}$ mice following oral gavage. $\boldsymbol{B}$. Amount of ${ }^{54} \mathrm{Mn}$ in brain of WT and Zip $14 \mathrm{KO}$ mice following subcutaneous injection. C, Amount of ${ }^{65} \mathrm{Zn}$ in brain tissue of WT and Zip $14 \mathrm{KO}$ mice following oral gavage. D, Amount of ${ }^{65} \mathrm{Zn}$ in brain of WT and Zip14 KO mice following subcutaneous injection. $E$, Transcript of DMT1. Values are reported as the mean \pm SEM. $N=3-7$. Student's $t$ test for WT and Zip14 K0 comparison for each gender.

motor activity chambers (Taylor et al., 2010), balance beam traversal, pole descent, hindlimb clasping reflex, cylinder test, and inverted grip test. Zip14 KO mice displayed significantly less horizontal activity, total distance, moving time, clockwise revolution, counterclockwise revolution, and margin distance. In contrast, resting time was significantly greater when compared with WT controls (Fig. 6). The Zip14 KO mice required significantly more time to cross a balance beam and made a greater number of mistakes compared with WT control mice (Fig. 7A). Furthermore, pole descent time for Zip14KO mice was significantly greater than that of WT mice (Fig. $7 B$ ). The hindlimb clasping reflex was also defective in Zip14 KO mice (Fig. 7C). Forelimb activity in cylinder test was significantly lower in Zip14 $\mathrm{KO}$ mice (Fig. 7D). Limb strength was not different between Zip14 KO and WT mice, as measured by the inverted grid assay (Fig. 7E); therefore, outcomes in motor tests were not due to the physical strength. These data collectively suggest that motor activities were impaired in Zip14 KO mice similar to those exhibited in Parkinson's disease patients. 


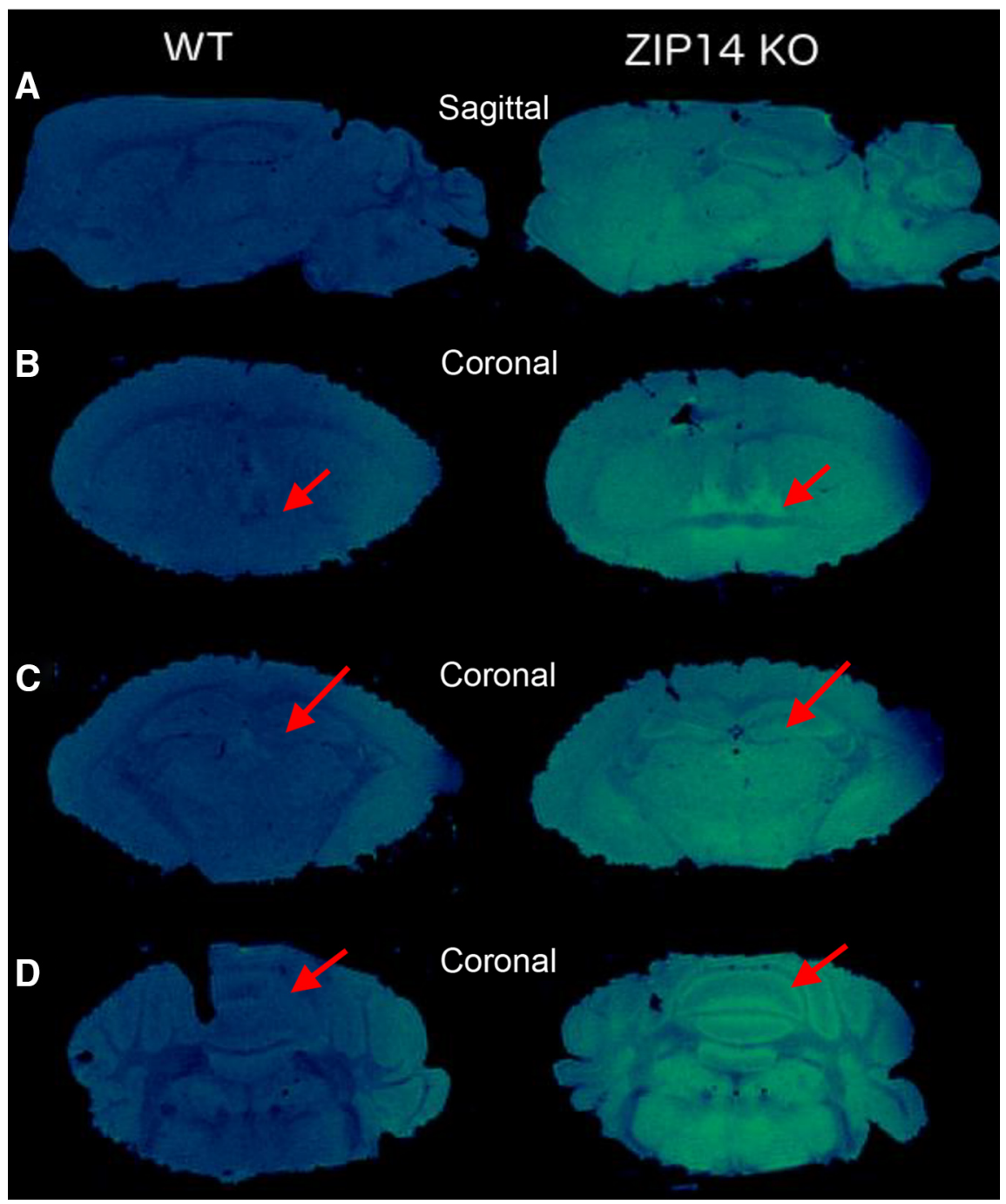

Figure 5. Representative T1-weighted 3D FLASH MRI scans of WT and Zip 14 KO mouse brains. Postmortem brain scans were acquired at 17.6 tesla. $\boldsymbol{A}$, Sagittal view showing greater overall signal intensity in Zip14 KO mice than in WT mice. $\boldsymbol{B}$, Coronal view at the level of the striatum highlighting the bed nucleus of stria terminalis (red arrow). $\boldsymbol{C}$, Hippocampal CA3/dentate region. D, Cerebellum.

Gastrointestinal motility is commonly disturbed in Parkinson's disease (Jost, 2010). To test GI motility, WT and Zip14 KO mice were gavaged with TRITC dextran, and fluorescence was measured with suspensions of the luminal contents. While there was no difference in the content of stomach and proximal intestine, significantly higher and lower fluorescence were detected in luminal contents of distal intestine and colon, respectively, in Zip14 KO mice when compared with WT mice (Fig. $7 F$ ). Moreover, total output of fecal pellets was significantly lower in Zip14 KO mice (Fig. $7 G$ ). These data suggest that, similar to patients with Parkinson's disease, there was less motility in the lower gastrointestinal track of Zip14 KO mice.

\section{Zip14 deletion increases indices of neuroinflammation and brain injury}

Manganese-related brain injury and neuroinflammation are common features of neurodegenerative disorders (Guilarte, 2013; Horning et al., 2015). Therefore, we measured $I L-6, I L-1 \beta$, and Tnf- $\alpha$ transcripts in brain tissue. Tnf- $\alpha$ transcripts were significantly higher in Zip14 KO mice of both genders compared with WT controls (Fig. 8A). The transcript abundance for $I L-6$ and $I L-1 B$ did not change (data not shown). In agreement with $\operatorname{Tnf}-\alpha$ upregulation, we have found a greater abundance of phosphorylated nuclear factor $-\kappa \mathrm{B}(\mathrm{NF}-\kappa \mathrm{B})$ protein in the brains of Zip14 KO mice (Fig. 8A). Furthermore, TSPO was more abundant in the brains of Zip14 KO mice (Fig. 8A), which is reflective of neuroinflammation and injury.

$M n$ and $Z n$ are differentially redistributed during inflammation

To investigate the relationship between brain manganese accumulation and neuroinflammation/neurodegeneration in Zip14 $\mathrm{KO}$ mice, we induced systemic inflammation via LPS administration. Our previous studies have linked changes in zinc homeostasis and ZIP14 expression in response to acute inflammation induced by LPS (Liuzzi et al., 2005; Aydemir et al., 2012b). For example, LPS increases ZIP14 expression in multiple tissues, including liver, adipose, and muscle, and is accompanied by hypozincemia, which is a hallmark of acute inflammation (Aydemir et al., 2012b). Considering the influence of ZIP14 on manganese accumulation, we compared the metabolism of zinc and manganese during acute inflammation. As shown previously in Zip14-null mice, acute inflammation does not reduce serum zinc levels (Liuzzi et al., 2005). LPSinduced hypozincemia was demonstrated here with both serum ${ }^{65} \mathrm{Zn}$ from an oral dose and zinc as measured by AAS (Fig. $8 B, C)$. Surprisingly, blood manganese levels were higher following LPS administration, a response that was greatly amplified in the Zip14 $\mathrm{KO}$ mice (Fig. 8B). Of note was the markedly greater ${ }^{54} \mathrm{Mn}$ content in brains of the Zip14 KO mice, but that LPS treatment attenuated that effect. Whole-blood ${ }^{54} \mathrm{Mn}$ content was far greater in the Zip14 KO mice, and the difference was accentuated by LPS treatment (Fig. $8 \mathrm{C}$ ). By comparison, ${ }^{65} \mathrm{Zn}$ accumulation in the brain was not influenced by LPS in WT mice but produced greater ${ }^{65} \mathrm{Zn}$ accumulation in the brain of Zip14 KO mice (Fig. 8C). Of major interest is that acute LPS administration accentuated ZIP14 expression in brain (Fig. $8 D$ ). Furthermore, Zip14 ablation magnified the influence of LPS on brain TNF $\alpha$ levels (Fig. $8 D$ ). These data suggest that enhanced manganese accumulation by the brain and concurrent brain injury in $Z i p 14 \mathrm{KO}$ mice are related to defective metabolic handling and elimination of manganese. They also are suggestive of a neuroprotective influence of ZIP14.

\section{Limitation of brain manganese with dietary zinc supplementation}

Manganese is a substrate for ZIP14 transport in vitro, as is zinc, which is considered as the natural substrate (Pinilla-Tenas et al., 2011). To evaluate a potential strategy for the limitation of manganese deposition by zinc supplementation, we compared 

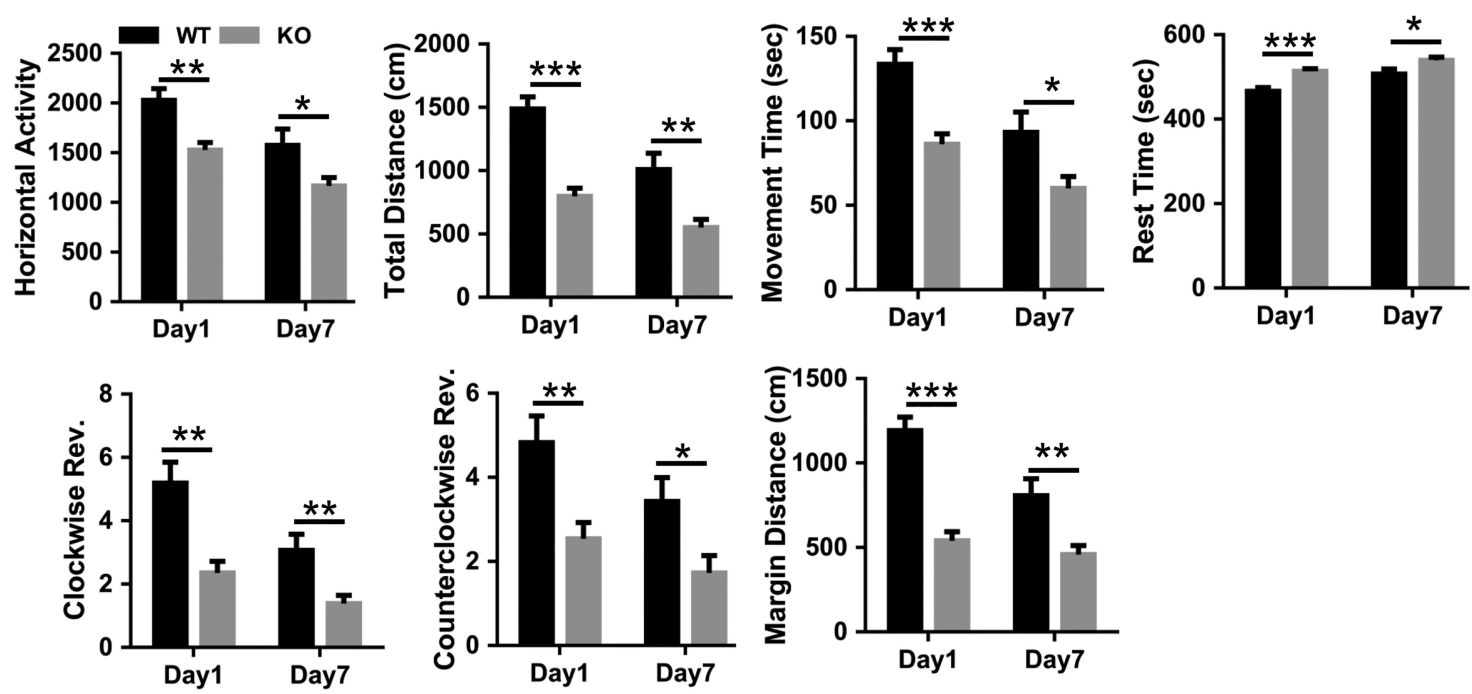

Figure 6. Comparison of spontaneous open field locomotor activity between WT and Zip $14 \mathrm{KO}$ mice. Mice were placed in open field activity test chambers individually and data were collected for 30 min using the Versamax activity monitor and analyzer software system. Values are reported as the mean \pm SEM. $N=4-12$ (equal number of female and male mice were included). ${ }^{*} p<0.05$, ${ }^{* *} p<0.01,{ }^{* * *} p<0.001$. Student's $t$ test for WT and Zip 14 KO mice comparison for each day.
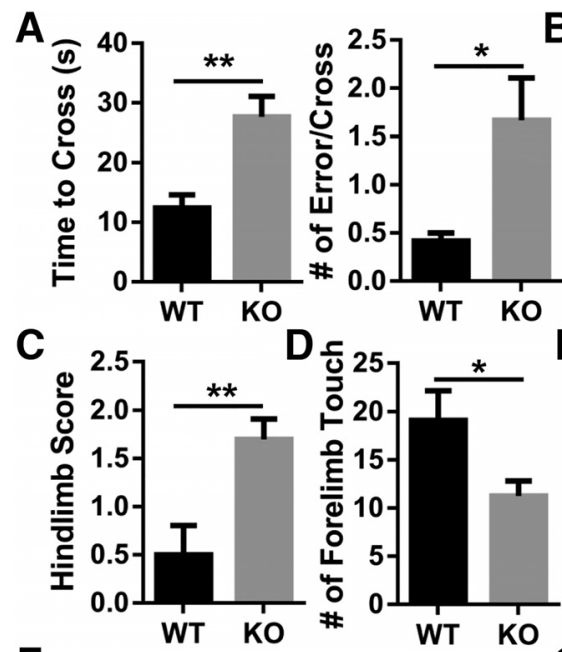

$\mathbf{F}$
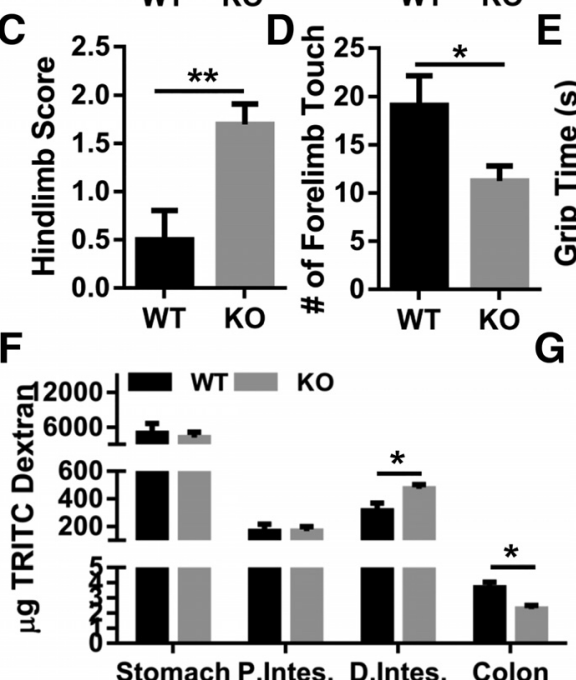

G
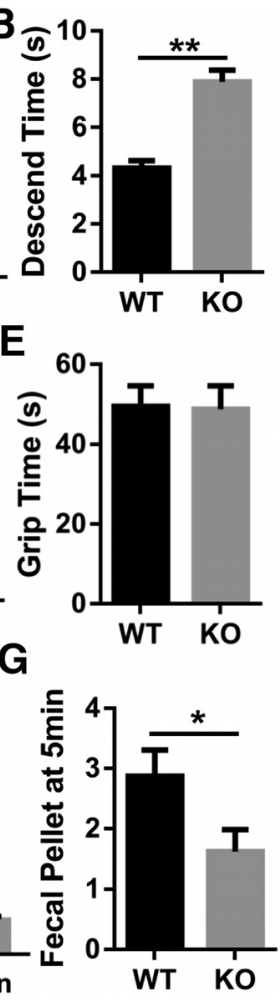

Figure 7. Comparison of motor and gastrointestinal function between WT and Zip14 KO mice. $A$, Time to cross of balance beam and the number of errors made per cross were counted. $B$, Time to descend on the pole was counted. $C$, Hindlimb scores were given to mice based on the number of hindlimb clasps. $\boldsymbol{D}$, Forelimb activity in a translucent cylinder was counted for $5 \mathrm{~min}$. $\boldsymbol{E}$, Limb strength was measured by inverted grip test. $\boldsymbol{F}$, Mice were given TRITC-Dextran $(40,000)$ and after $2 \mathrm{~h} \mathrm{Gl}$ contents were collected to measure fluorescence by spectrofluorometry. $\mathbf{G}$, Mice were placed in a translucent cylinder, and fecal output was counted for $5 \mathrm{~min}$. Values are reported as the mean \pm SEM. $N=4-8$ (equal number offemale and male mice were included). ${ }^{*} p<0.05$, ${ }^{* *} p<$ $0.01,{ }^{* * *} p<0.001$. Student's $t$ test for WT and Zip 14 K0 mice comparison.

\footnotetext{
${ }^{54} \mathrm{Mn}$ uptake by brain 2 weeks after the mice were placed on a zinc-supplemented diet containing $180 \mathrm{mg} \mathrm{Zn/kg}$. As shown in Figure 9, the supplemented diet significantly lowered brain ${ }^{54} \mathrm{Mn}$ uptake in the Zip14 KO mice. This finding suggests that
}

zinc administered orally has the potential to serve as a therapeutic option to limit manganese accumulation in the CNS.

\section{Discussion}

A characteristic that manganese shares with other essential trace element micronutrients, specifically iron, copper, and zinc, is tightly regulated homeostasis (Buchman, 2014; Collins, 2014; King and Cousins, 2014; Wessling-Resnick, 2014).

Substantial evidence has shown that manganese uses metabolic pathways associated with iron for absorption and cellular uptake/efflux (Kim et al., 2013; Buchman, 2014; Horning et al., 2015; Seo and Wessling-Resnick, 2015). Marked differences of opinion exist, however, related to the actual mechanisms involved. For example, DMT1 has been suggested as the major manganese transporter for enteric absorption (Garrick et al., 2003). That is at variance with evidence from an intestine-specific Dmt1 knock-out mouse suggesting that DMT1 does not have a role in manganese absorption (Shawki et al., 2015). In support of that result, we did not find a change in DMT1 protein levels in the intestines of WT and Zip14 KO mice. A similar finding regarding DMT1 expression was made with the loss-of-function zebrafish mutant model (Tuschl et al., 2016). The iron exporter FPN1 may export manganese from enterocytes at the basolateral surface and into the circulation (Buchman, 2014). The flatiron mutation in mice produces an FPN1 deficiency causing a decrease in blood, liver, and biliary manganese levels and a decrease in absorption of orally administered ${ }^{54} \mathrm{Mn}$ (Seo and Wessling-Resnick, 2015). Transferrin can bind manganese (Aisen et al., 1969). In that regard it is of interest that TFR1 is located at the basolateral membrane of enterocytes (Chen et al., 2015). That orientation suggests that some manganese could enter a serosal-to-mucosal excretory pathway through TFR1.

Neurons may acquire manganese through uptake via the TFR mechanism (Suárez and Eriksson, 1993). In addition the metal transporter ZnT10 has been shown to transport manganese from neuronal cells (Leyva-Illades et al., 2014; Nishito et al., 2016). Downregulation of ZnT10 would be expected to increase cellular manganese retention. However, our results show that Znt10 mRNA expression was not influenced in tissues, including the brain of WT or KO mice. Nevertheless, human ZnT10 mutations 

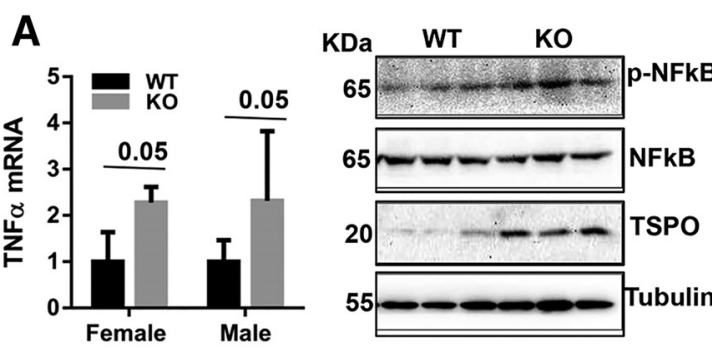

B
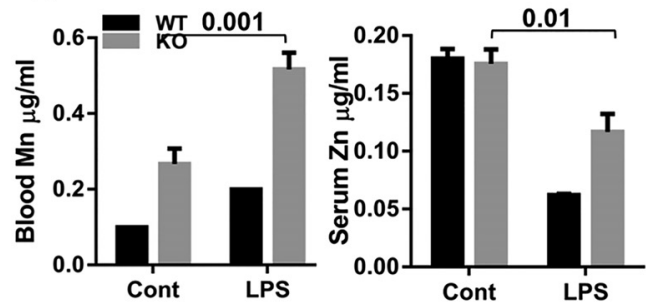
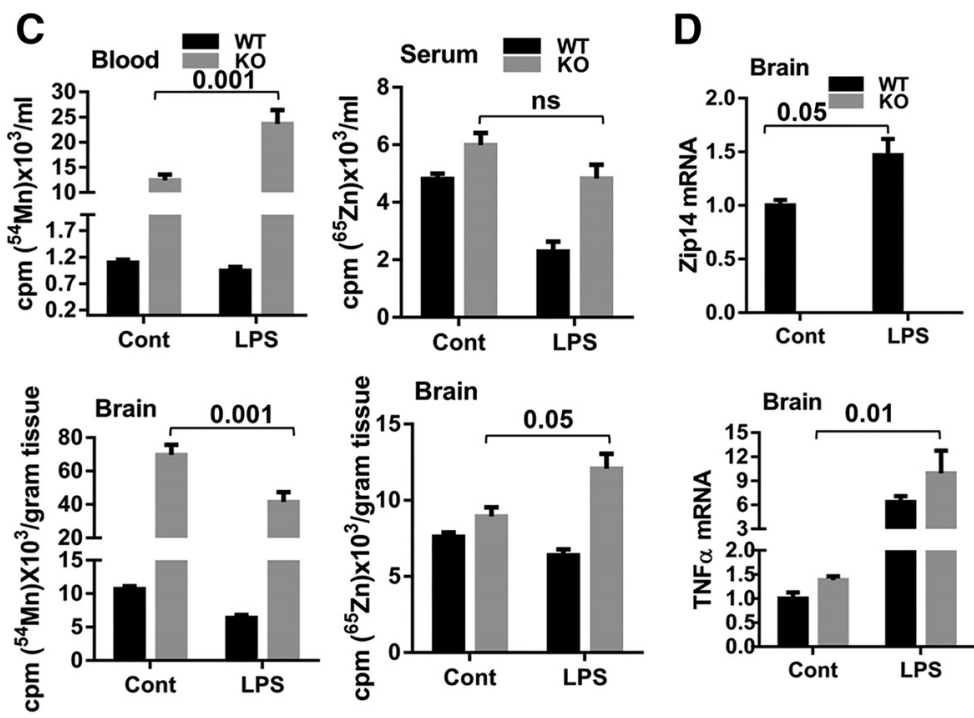

Figure 8. Mn and Zn differentially redistributed during inflammation induced by LPS. $A$, Relative expression of brain TNF $\alpha$ and the abundance of neurodegeneration marker proteins at steady state. $\boldsymbol{B}$, Concentrations of $\mathrm{Mn}$ and Zn in blood and serum were measured by AAS. C, Comparison of ${ }^{54} \mathrm{Mn}$ and ${ }^{65} \mathrm{Zn}$ metabolism during inflammation. $\boldsymbol{D}$, Relative expressions of Zip 14 and TNF $\alpha$ were measured by qPCR. Values are reported as the mean \pm SEM. $N=4-7$. ANOVA/Tukey's test was used for multiple comparisons.
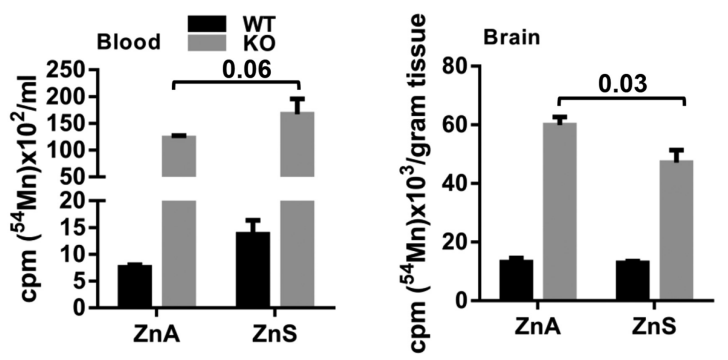

Figure 9. Influence of dietary zinc supplementation on ${ }^{54} \mathrm{Mn}$ metabolism. WT and Zip14 K0 mice were either fed with zinc adequate (ZnA) or zinc supplemented (ZnS) diet for 2 weeks. At the end of dietary feeding, mice were given ${ }^{54} \mathrm{Mn}$ via subcutaneous injection. At $4 \mathrm{~h}$ postinjection, the amounts of ${ }^{54} \mathrm{Mn}$ were measured in blood and brain. Values are reported as the mean \pm SEM. $N=4-7$ (equal number of female and male mice were included). ANOVA/ Tukey's test was used for multiple comparisons.

have been shown to be associated with hypermanganesemia (Qadri et al., 2004; Tuschl et al., 2012). Hence, when mutated, the gene may produce a change-of-function/location for ZnT10 protein.

ZIP14 is capable of transporting zinc (Liuzzi et al., 2005; Liuzzi et al., 2006). The role of ZIP14 in zinc transport leading to multiple physiologic effects is now established (Aydemir et al., 2012a,b, 2016; Guthrie et al., 2015; Wessels and Cousins, 2015). The manganese-transporting abilities of ZIP14 have been investigated through in vitro approaches (Girijashanker et al., 2008; Pinilla-Tenas et al., 2011; Fujishiro et al., 2014). However, highly relevant to the manganese transport role of ZIP 14 in vivo is the recent report identifying homozygous mutations of ZIP14 in a cohort of children with clinical hypermanganesemia and progressive parkinsonism-dystonia (Tuschl et al., 2016). It was proposed that those mutations in ZIP14 produced altered manganese homeostasis in vivo based upon evidence from a loss-of-function zebrafish mutant model. Those experiments prompted us to investigate the manganese-transporting ability of ZIP14 using a conventional Zip14 knock-out mouse model. Taking a systems approach, we have identified a ZIP14 dysfunction syndrome producing spon-

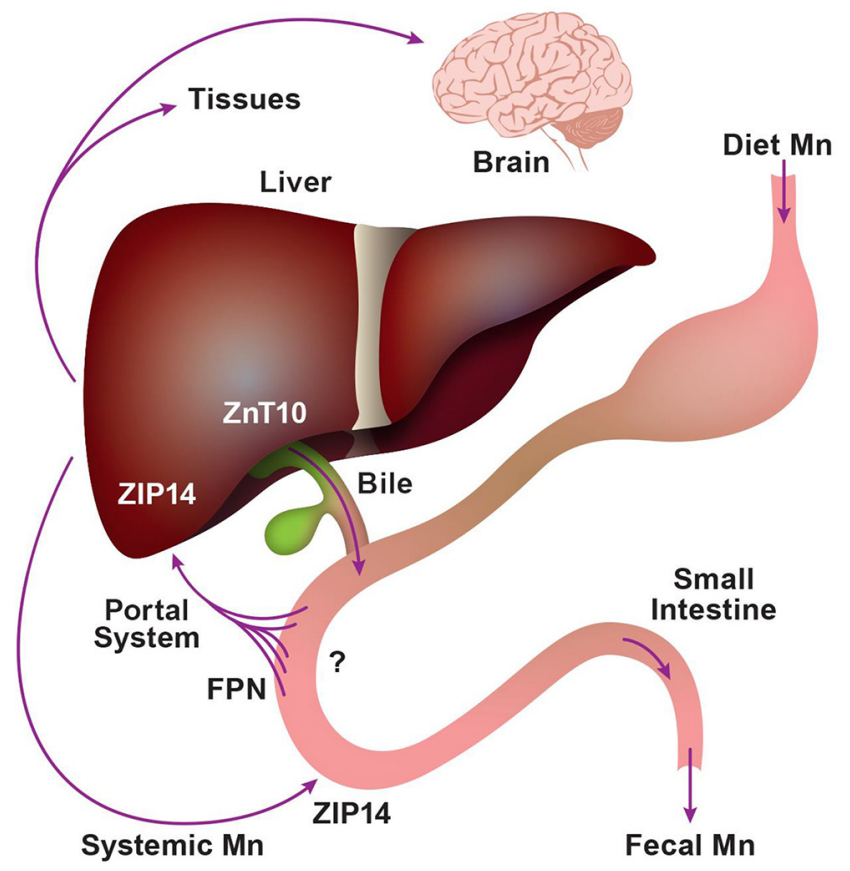

Figure 10. Model for transporter activity for mammalian manganese absorption, hepatic uptake, and endogenous excretion. The transporters required for manganese uptake by enterocytes at the apical membrane have not been established. FPN facilitates manganese efflux from enterocytes into the portal circulation. Hepatocytes use ZIP14 as a major transporter for manganese uptake. ZnT10 is responsible for manganese secretion into the biliary excretory pathway. ZIP14 facilitates systemic manganese transport into enterocytes at the basolateral membrane. Without normal ZIP14 function, manganese is diverted to systemic circulation and tissue uptake, particularly the brain.

taneous manganism in mice maintained with normal husbandry. The whole-blood manganese level was twofold greater, and, remarkably, the manganese deposition in the brain was fivefold to sixfold greater in the Zip14 KO mice. Manganese accumulation was greater in males than in females. This gender difference is reflective of the longer half-life of absorbed ${ }^{54} \mathrm{Mn}$ observed in male human subjects 
(Finley et al., 1994). Moreover, the greater manganese accumulation in male mice is in agreement with the higher incidence of Parkinson's disease in males (Van Den Eeden et al., 2003).

The early ${ }^{54} \mathrm{Mn}$ studies of Cotzias (Bertinchamps et al., 1966) demonstrated that the liver has a primary role for rapid clearance of newly absorbed manganese. The lower liver ${ }^{54} \mathrm{Mn}$ levels in the KO mice suggest that the absence of ZIP14 decreases hepatic manganese uptake and transit. Early transport studies with isolated rat hepatocytes showed that a high-affinity transport system exists for manganese (Schramm and Brandt, 1986). ZIP14 may be a component of that high-affinity transport system. ZIP8 expression was upregulated in the Zip14 KO mice possibly to compensate for the lack of ZIP14. Also of note is that despite the increases in whole-blood manganese levels seen with Zip14 ablation, serum zinc and iron concentrations are the same in both WT and Zip14 KO mice (Aydemir et al., 2012b). In that regard, our results are similar to those recently shown for the human patients with mutated Zip14 where the whole-blood manganese level was elevated, but whole-blood levels for iron, copper, zinc, and cadmium were within normal ranges (Tuschl et al., 2016). Furthermore, the apparent normal handling of ${ }^{54} \mathrm{Mn}$ in liver and gallbladder in both WT and Zip14 KO mice when administered by gavage suggests that ZIP14 is not involved in enteric manganese absorption.

Our model for manganese homeostasis includes ZIP14 localization to the basolateral membrane of enterocytes (Fig. 10). That localization and the deficiency of intestinal ZIP14 in the KO mice were confirmed in this report. Previously, we have proposed that intestinal ZIP14 in mice functions to provide endogenous zinc for functions such as tight junction integrity and/or for zinc replenishment for the proliferating intestinal epithelium (Guthrie et al., 2015). Hence, a role for enterocyte ZIP14 in manganese excretion cannot be excluded. Since enterocytes are constantly being renewed, manganese in these cells would be lost through desquamation. Subcutaneous administration of ${ }^{54} \mathrm{Mn}$ produced significant increases in radioactivity found in brain, whole blood, and peripheral tissues. In contrast, subcutaneous administration resulted in less radioactivity from ${ }^{54} \mathrm{Mn}$ recovered in the intestinal lumen of the Zip14 KO mice compared with that in WT controls, suggesting that manganese excretion via the gastrointestinal tract is markedly reduced in mice without ZIP14. A serosal to mucosal route for ${ }^{54} \mathrm{Mn}$ excretion has been proposed (Bertinchamps et al., 1966).

The current experiments establish a number of points about ZIP14. First, ZIP14 is not needed for the brain to acquire manganese. Second, ZIP14 is not necessary for manganese absorption, but is essential for excretion. The extent of manganese accumulation in the Zip14 KO mice (Fig. 5) is sufficient to enhance intensity in T1-weighted magnetic resonance images. Brain-mapping studies in rodents have previously made use of manganese-enhanced MRI to assess brain activity (Sepúlveda et al., 2012; Perez et al., 2013; Malkova et al., 2014). Such studies require administration of $\mathrm{MnCl}_{2}$ in the range of $70-88 \mathrm{mg} \mathrm{Mn} / \mathrm{kg}$ to provide enhancement of contrast related to manganese accumulation in active neurons. Manganese sequestration is thought to reflect the activity of neural circuits. Third, Zip14 ablation increases zinc concentrations of the total brain but does not change concentrations of iron. This latter finding argues against a role for ZIP14 in iron transport under normal physiologic conditions. Fourth, oral zinc supplementation may limit brain manganese accumulation; however, further studies on the therapeutic value of zinc would need to include evaluation of the dose level, form, and time of therapeutic intervention. Finally, ZIP14 ablation leads to motor dysfunction in mice. The mice used in these experiments were young adults.
Manganese accumulation would be expected to increase with age. That would be consistent with the progression of signs of Parkinson's disease with age (Van Den Eeden et al., 2003).

While manganese accumulates in brains of Zip14 KO mice, the question remains as to the function of ZIP14 in neuronal cells. The most likely possibility is that normally ZIP14 zinc-transporting activity is needed to prevent mismetallation of essential metalloproteins. Recently, the dopamine transporter has been shown to have a $\mathrm{Zn}^{2+}$ binding site that regulates activity by an allosteric mechanism (Li et al., 2017). Manganese has a low affinity for this binding site. However, a $\mathrm{Mn} / \mathrm{Zn}$ competition for the site due to defective ZIP14 could influence dopamine transport. In turn, this could relate to impaired dopamine release associated with manganese accumulation (Guilarte, 2013). In addition, as pointed out above, the response of Zip14 to proinflammatory conditions in multiple tissues suggests that there could be a similar response in the mammalian brain. The studies focusing on liver and adipose tissue suggest that ZIP14 during inflammation contributes of phosphatase inhibition and suppression of NF- $\kappa$ B and STAT3 signaling (Aydemir et al., 2012b; Troche et al., 2016). Cytokines produced via glial stimulation may induce similar responses in neuronal cells as has been proposed previously (Horning et al., 2015). Such cytokine release may induce neuronal ZIP14, possibly needed for control of zinc-dependent signaling. This neuronal zinc delivery could simultaneously contribute to manganese delivery to neurons as a consequence of neuroinflammation.

In summary, Figure 10 presents our interpretation of the importance of ZIP14 in manganese homeostasis in mice based on the data presented here. We propose that ZIP14 is not required for enteric manganese absorption or for manganese uptake into the brain. Furthermore, the stoichiometry of zinc and manganese in portal plasma is such that hepatic ZIP14 serves a gatekeeper role to shuttle manganese out of the systemic circulation and into hepatocytes for transport to excretory pathways. Ablation of Zip14 deletes this protective role and leads to manganese accumulation in brain with concomitant signatures of locomotor dysfunction and neurodegeneration as seen in Parkinson's disease.

\section{References}

Aisen P, Aasa R, Redfield AG (1969) The chromium, manganese, and cobalt complexes of transferrin. J Biol Chem 244:4628-4633. Medline

Aydemir TB, Liuzzi JP, McClellan S, Cousins RJ (2009) Zinc transporter ZIP8 (SLC39A8) and zinc influence IFN-gamma expression in activated human T cells. J Leukoc Biol 86:337-348. CrossRef Medline

Aydemir TB, Sitren HS, Cousins RJ (2012a) The zinc transporter Zip14 influences c-Met phosphorylation and hepatocyte proliferation during liver regeneration in mice. Gastroenterology 142:1536-1546.e5. CrossRef Medline

Aydemir TB, Chang SM, Guthrie GJ, Maki AB, Ryu MS, Karabiyik A, Cousins RJ (2012b) Zinc transporter ZIP14 functions in hepatic zinc, iron and glucose homeostasis during the innate immune response (endotoxemia). PLoS One 7:e48679. CrossRef Medline

Aydemir TB, Troche C, Kim MH, Cousins RJ (2016) Hepatic ZIP14mediated zinc transport contributes to endosomal insulin receptor trafficking and glucose metabolism. J Biol Chem 291:23939-23951. CrossRef Medline

Bertinchamps AJ, Miller ST, Cotzias GC (1966) Interdependence of routes excreting manganese. J Physiol 211:217-224. Medline

Boycott KM, Beaulieu CL, Kernohan KD, Gebril OH, Mhanni A, Chudley AE, Redl D, Qin W, Hampson S, Kury S, Tetreault M, Puffenberger EG, Scott JN, Bezieau S, Reis A, Uebe S, Schumacher J, Hegele RA, McLeod DR, Gálvez-Peralta M, et al (2015) Autosomal-recessive intellectual disability with cerebellar atrophy syndrome caused by mutation of the manganese and zinc transporter gene SLC39A8. Am J Hum Genet 97:886-893. CrossRef Medline 
Buchman AA (2014) Manganese. In: Modern nutrition in health and disease, Ed 11 (Ross AC, ed), pp 238-244. Philadelphia: Wolters Kluwer Health/Lippincott Williams \& Wilkins.

Burton NC, Guilarte TR (2009) Manganese neurotoxicity: lessons learned from longitudinal studies in nonhuman primates. Environ Health Perspect 117:325-332. CrossRef Medline

Chen AC, Donovan A, Ned-Sykes R, Andrews NC (2015) Noncanonical role of transferrin receptor 1 is essential for intestinal homeostasis. Proc Natl Acad Sci U S A 112:11714-11719. CrossRef Medline

Chua AC, Morgan EH (1997) Manganese metabolism is impaired in the Belgrade laboratory rat. J Comp Physiol B 167:361-369. CrossRef Medline

Collins JF (2014) Copper. In: Modern nutrition in health and disease, Ed 11 (Ross AC, ed), pp 206-216. Philadelphia: Wolters Kluwer Health/Lippincott Williams \& Wilkins.

Finley JW, Johnson PE, Johnson LK (1994) Sex affects manganese absorption and retention by humans from a diet adequate in manganese. J Clin Nutr 60:949-955.

Freeland-Graves JH, Mousa TY, Kim S (2016) International variability in diet and requirements of manganese: causes and consequences. J Trace Elem Med Biol 38:24-32. CrossRef Medline

Fujishiro H, Yoshida M, Nakano Y, Himeno S (2014) Interleukin-6 enhances manganese accumulation in SH-SY5Y cells: implications of the up-regulation of ZIP14 and the down-regulation of ZnT10. Metallomics 6:944-949. CrossRef Medline

Garrick MD, Dolan KG, Horbinski C, Ghio AJ, Higgins D, Porubcin M, Moore EG, Hainsworth LN, Umbreit JN, Conrad ME, Feng L, Lis A, Roth JA, Singleton S, Garrick LM (2003) DMT1: a mammalian transporter for multiple metals. Biometals 16:41-54. CrossRef Medline

Girijashanker K, He L, Soleimani M, Reed JM, Li H, Liu Z, Wang B, Dalton TP, Nebert DW (2008) Slc39a14 gene encodes ZIP14, a metal/bicarbonate symporter: similarities to the ZIP8 transporter. Mol Pharmacol 73: 1413-1423. CrossRef Medline

Guilarte TR (2013) Manganese neurotoxicity: new perspectives from behavioral, neuroimaging, and neuropathological studies in humans and non-human primates. Front Aging Neurosci 5:23. CrossRef Medline

Guthrie GJ, Aydemir TB, Troche C, Martin AB, Chang SM, Cousins RJ (2015) Influence of ZIP14 (slc39A14) on intestinal zinc processing and barrier function. Am J Physiol Gastrointest Liver Physiol 308:G171G178. CrossRef Medline

Horning KJ, Caito SW, Tipps KG, Bowman AB, Aschner M (2015) Manganese is essential for neuronal health. Annu Rev Nutr 35:71-108. CrossRef Medline

Huang L, Tepaamorndech S (2013) The SLC30 family of zinc transporters-a review of current understanding of their biological and pathophysiological roles. Mol Aspects Med 34:548-560. CrossRef Medline

Jeong J, Eide DJ (2013) The SLC39 family of zinc transporters. Mol Aspects Med 34:612-619. CrossRef Medline

Jost WH (2010) Gastrointestinal dysfunction in Parkinson's disease. J Neurol Sci 289:69-73. CrossRef Medline

Kambe T, Tsuji T, Hashimoto A, Itsumura N (2015) The physiological, biochemical, and molecular roles of zinc transporters in zinc homeostasis and metabolism. Physiol Rev 95:749-784. CrossRef Medline

Kim J, Buckett PD, Wessling-Resnick M (2013) Absorption of manganese and iron in a mouse model of hemochromatosis. PLoS One 8:e64944. CrossRef Medline

King JC, Cousins RJ (2014) Zinc. In: Modern nutrition in health and disease, Ed 11 (Ross AC, ed), pp 189-205. Philadelphia: Wolters Kluwer Health/Lippincott Williams \& Wilkins.

Leyva-Illades D, Chen P, Zogzas CE, Hutchens S, Mercado JM, Swaim CD, Morrisett RA, Bowman AB, Aschner M, Mukhopadhyay S (2014) SLC30A10 is a cell surface-localized manganese efflux transporter, and parkinsonism-causing mutations block its intracellular trafficking and efflux activity. J Neurosci 34:14079-14095. CrossRef Medline

Li Y, Mayer FP, Hasenhuetl PS, Burtscher K, Schicker K, Sitte HH, Freissmuth M, Sandter W (2017) Occupancy of the zinc-binding site by transition metals decreases the substrate affinity of the human dopamine transporter by an allosteric mechanism. J Biol Chem 292:4235-4243. CrossRef Medline

Lichten LA, Cousins RJ (2009) Mammalian zinc transporters: nutritional and physiologic regulation. Annu Rev Nutr 29:153-176. CrossRef Medline
Lichten LA, Liuzzi JP, Cousins RJ (2009) Interleukin-1beta contributes via nitric oxide to the upregulation and functional activity of the zinc transporter Zip14 (Slc39a14) in murine hepatocytes. Am J Physiol Gastrointest Liver Physiol 296:G860-G867. CrossRef Medline

Liuzzi JP, Lichten LA, Rivera S, Blanchard RK, Aydemir TB, Knutson MD, Ganz T, Cousins RJ (2005) Interleukin-6 regulates the zinc transporter Zip14 in liver and contributes to the hypozincemia of the acute-phase response. Proc Natl Acad Sci U S A 102:6843-6848. CrossRef Medline

Liuzzi JP, Aydemir F, Nam H, Knutson MD, Cousins RJ (2006) Zip14 (Slc39a14) mediates non-transferrin-bound iron uptake into cells. Proc Natl Acad Sci U S A 103:13612-13617. CrossRef Medline

Malkova NV, Gallagher JJ, Yu CZ, Jacobs RE, Patterson PH (2014) Manganese-enhanced magnetic resonance imaging reveals increased DOI-induced brain activity in a mouse model of schizophrenia. Proc Natl Acad Sci U S A 111:E2492-D2500. CrossRef Medline

Nishito Y, Tsuji N, Fujishiro H, Takeda TA, Yamazaki T, Teranishi F, Okazaki F, Matsunaga A, Tuschl K, Rao R, Kono S, Miyajima H, Narita H, Himeno S, Kambe T (2016) Direct comparison of manganese detoxification/efflux proteins and molecular characterization of ZnT10 protein as a manganese transporter. J Biol Chem 291:14773-14787. CrossRef Medline

O’Neal SL, Zheng W (2015) Manganese toxicity upon overexposure: a decade in review. Curr Environ Health Rep 2:315-328. CrossRef Medline

Park JH, Hogrebe M, Grüneberg M, DuChesne I, von der Heiden AL, Reunert J, Schlingmann KP, Boycott KM, Beaulieu CL, Mhanni AA, Innes AM, Hörtnagel K, Biskup S, Gleixner EM, Kurlemann G, Fiedler B, Omran H, Rutsch F, Wada Y, Tsiakas K, et al (2015) SLC39A8 deficiency: a disorder of manganese transport and glycosylation. Am J Hum Genet 97:894903. CrossRef Medline

Peres TV, Schettinger MR, Chen P, Carvalho F, Avila DS, Bowman AB, Aschner M (2016) Manganese-induced neurotoxicity: a review of its behavioral consequences and neuroprotective strategies. BMC Pharmacol Toxicol 17: 57. CrossRef Medline

Perez PD, Hall G, Kimura T, Ren Y, Bailey RM, Lewis J, Febo M, Sahara N (2013) In vivo functional brain mapping in a conditional mouse model of human tauopathy (tauP301L) reveals reduced neural activity in memory formation structures. Mol Neurodegener 8:9. CrossRef Medline

Pinilla-Tenas JJ, Sparkman BK, Shawki A, Illing AC, Mitchell CJ, Zhao N, Liuzzi JP, Cousins RJ, Knutson MD, Mackenzie B (2011) Zip14 is a complex broad-scope metal-ion transporter whose functional properties support roles in the cellular uptake of zinc and nontransferrin-bound iron. Am J Physiol Cell Physiol 301:C862-C871. CrossRef Medline

Qadri I, Iwahashi M, Capasso JM, Hopken MW, Flores S, Schaack J, Simon FR (2004) Induced oxidative stress and activated expression of manganese superoxide dismutase during hepatitis $\mathrm{C}$ virus replication: role of JNK, p38 MAPK and AP-1. Biochem J 378:919-928. CrossRef Medline

Quadri M, Federico A, Zhao T, Breedveld GJ, Battisti C, Delnooz C, Severijnen LA, Di Toro Mammarella L, Mignarri A, Monti L, Sanna A, Lu P, Punzo F, Cossu G, Willemsen R, Rasi F, Oostra BA, van de Warrenburg BP, Bonifati V (2012) Mutations in SLC30A10 cause parkinsonism and dystonia with hypermanganesemia, polycythemia, and chronic liver disease. Am J Hum Genet 90:467-477. CrossRef Medline

Sampson TR, Debelius JW, Thron T, Janssen S, Shastri GG, Ilhan ZE, Challis C, Schretter CE, Rocha S, Gradinaru V, Chesselet MF, Keshavarzian A, Shannon KM, Krajmalnik-Brown R, Wittung-Stafshede P, Knight R, Mazmanian SK (2016) Gut microbiota regulate motor deficits and neuroinflammation in a model of Parkinson's disease. Cell 167:14691480.e12. CrossRef Medline

Schramm VL, Brandt M (1986) The manganese(II) economy of rat hepatocytes. Fed Proc 45:2817-2820. Medline

Seo YA, Wessling-Resnick M (2015) Ferroportin deficiency impairs manganese metabolism in flatiron mice. FASEB J 29:2726-2733. CrossRef Medline

Sepúlveda MR, Dresselaers T, Vangheluwe P, Everaerts W, Himmelreich U, Mata AM, Wuytack F (2012) Evaluation of manganese uptake and toxicity in mouse brain during continuous $\mathrm{MnCl} 2$ administration using osmotic pumps. Contrast Media Mol Imaging 7:426-434. CrossRef Medline

Shawki A, Anthony SR, Nose Y, Engevik MA, Niespodzany EJ, Barrientos T, Öhrvik H, Worrell RT, Thiele DJ, Mackenzie B (2015) Intestinal DMT1 is critical for iron absorption in the mouse but is not required for the 
absorption of copper or manganese. Am J Physiol Gastrointest Liver Physiol 309:G635-G647. CrossRef Medline

Stepens A, Logina I, Liguts V, Aldins P, Eksteina I, Platkājis A, Mārtinsone I, Tērauds E, Rozentāle B, Donaghy M (2008) A Parkinsonian syndrome in methcathinone users and the role of manganese. N Engl J Med 358: 1009-1017. CrossRef Medline

Suárez N, Eriksson H (1993) Receptor-mediated endocytosis of a manganese complex of transferrin into neuroblastoma (SHSY5Y) cells in culture. J Neurochem 61:127-131. CrossRef Medline

Taylor TN, Greene JG, Miller GW (2010) Behavioral phenotyping of mouse models of Parkinson's disease. Behav Brain Res 211:1-10. CrossRef Medline

Troche C, Aydemir TB, Cousins RJ (2016) Zinc transporter Slc39a14 regulates inflammatory signaling associated with hypertrophic adiposity. Am J Physiol Endocrinol Metab 310:E258-E268. CrossRef Medline

Tuschl K, Clayton PT, Gospe SM Jr, Gulab S, Ibrahim S, Singhi P, Aulakh R, Ribeiro RT, Barsottini OG, Zaki MS, Del Rosario ML, Dyack S, Price V, Rideout A, Gordon K, Wevers RA, Chong WK, Mills PB (2012) Syndrome of hepatic cirrhosis, dystonia, polycythemia, and hypermanga- nesemia caused by mutations in SLC30A10, a manganese transporter in man. Am J Hum Genet 90:457-466. CrossRef Medline

Tuschl K, Meyer E, Valdivia LE, Zhao N, Dadswell C, Abdul-Sada A, Hung CY, Simpson MA, Chong WK, Jacques TS, Woltjer RL, Eaton S, Gregory A, Sanford L, Kara E, Houlden H, Cuno SM, Prokisch H, Valletta L, Tiranti V, et al (2016) Mutations in SLC39A14 disrupt manganese homeostasis and cause childhood-onset parkinsonism-dystonia. Nat Commun 7:11601. CrossRef Medline

Van Den Eeden SK, Tanner CM, Bernstein AL, Fross RD, Leimpeter A, Bloch DA, Nelson LM (2003) Incidence of Parkinson's disease: variation by age, gender, and race/ethnicity. Am J Epidemiol 157:1015-1022. CrossRef Medline

Wessels I, Cousins RJ (2015) Zinc dyshomeostasis during polymicrobial sepsis in mice involves zinc transporter Zip14 and can be overcome by zinc supplementation. Am J Physiol Gastrointest Liver Physiol 309: G768-G778. CrossRef Medline

Wessling-Resnick, M (2014) Iron. In: Modern nutrition in health and disease, Ed 11 (Ross AC, ed), pp 176-188. Philadelphia: Wolters Kluwer Health/Lippincott Williams \& Wilkins. 